2010

\title{
Instructional Videocasts: Facilitating Learning in a Mobile World
}

Roisin Donnelly

Technological University Dublin, roisin.donnelly@tudublin.ie

Robert Hickey

Institute of Technology, Blanchardstown, robert.hickey@tudublin.ie

Follow this and additional works at: https://arrow.tudublin.ie/ltcart

Part of the Education Commons

\section{Recommended Citation}

Donnelly, R., Hickey, R., : Instructional Videocasts: Facilitating Learning in a Mobile World, CEBE Transactions, 2010.

This Article is brought to you for free and open access by the Learning Teaching \& Assessment at ARROW@TU Dublin. It has been accepted for inclusion in Articles by an authorized administrator of ARROW@TU Dublin. For more information, please contact arrow.admin@tudublin.ie, aisling.coyne@tudublin.ie, gerard.connolly@tudublin.ie.

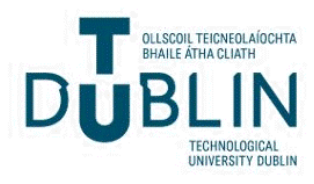




\title{
Instructional Videocasts: Facilitating Learning in a Mobile World
}

\author{
Robert Hickey, Lecturer in Brick and Stone laying \\ Institute of Technology Blanchardstown, Ireland robert.hickey@itb.ie \\ Roisin Donnelly \\ Dublin Institute of Technology, Ireland roisin.donnelly@itb.ie
}

\begin{abstract}
This paper critically discusses the new opportunities unique to the use of mobile platforms to complement formal learning with informal learning in an apprenticeship context. It begins with an outline of a problem identified by the teacher-researcher with phase six apprentice bricklaying students achieving psycomotor learning outcomes, mainly due to high student numbers and limited available workshop time. A solution to this problem is presented through the facilitation of the students using eleven short instructional video demonstrations on mobile phones to optimise their time. These were uploaded to the memory cards of the students' mobile phones. Within an action research approach, data was collected from sixteen students using a combination of a survey, a practical assessment, a focus group interview, and through keeping a research diary. The study showed, all of the students were in favour of using their mobile phones for just-in-time training and more than $90 \%$ wanted to utilise this method of learning on their work sites in the future. Ninety five percent $95 \%$ found the picture quality of the videos good on their standard mobile phones and had experienced limited technical difficulties. Most importantly, the study showed that the use of mLearning was more effective for apprentice students being enabled to achieve practical learning outcomes than the previous face-to-face training alone.
\end{abstract}

Keywords: Apprenticeship, just-in-time training, mLearning, videocasts. 


\section{Introduction}

Apprenticeships can be traced as far back as the Babylonian Code of Hammurabi 2100 B.C. (O'Toole, 2007). At that time there was one apprentice assigned to one master and initially, they gave detailed direction to the apprentice while acting as a guide for their learning. Now the ratio has increased to sixteen to one but the master is still required to give detailed direction and guidance to the student. This has created some obvious problems with information, knowledge and skills transfer being diluted, a point which has been raised at many national meetings of Irish and international vocational educators in the past.

Mobile learning is now being regarded as a transformative learning opportunity, representing a significant means of augmenting formal training (Quinn, 2011). The use of video has been successfully used for teaching, learning and training for many years (Zuber-Skerrit, 1984; Ellington et al., 1993; Barford and Weston, 1997; Maier and Warren, 2000; Macurik et al., 2008). Through advancements in technology, videos have become digitised, making them more versatile to use. Indeed Macurik et al. (2008) found in their study on video training for staff compared with live training that "video training is more efficient regarding time" (p.143). The streaming of digital videos for learning and teaching over the Internet has become very popular over the past ten or so years (Brett, 2008). This has been extended to mobile devices including mobile phones in recent years, but with varied success, mainly due to problems with wifi (Wireless Fidelity) availability and connection (Shudong and Higgins, 2006; Arrigo et al., 2008; Cochrane, 2008). Fortunately in the past few years, the memory and storage capability on mobile phones has increased dramatically. Most new mobile phones now have the capacity to take a memory card of at least 1GB in size which can store hours of video. This has increased the potential for the use of mobile phones in teaching, learning and training. Maniar (2008) points out that "Video can cater for different learning styles, specifically students who are 'visual learners' (p.53).

This project makes use of video to answer the needs of what Gray (2009) calls visual learners. Brickwork is used as a highly visual, decorative method of construction, e.g. using an axed segmental arch to bridge an opening; this is where every brick in the arch is cut to a wedge shape and built to the contour of a segment of a circle. Therefore the ability of the student to master the skills required to produce a high quality decorative feature such as an arch are essential. Through an exploration of mLearning, the project will investigate the use of just-in-time training in the form of instructional video demonstrations stored on the student's own mobile phones. It will examine the students' perception of how effective this method of learning is and measure its level of appeal. The specific research question is "can using mobile phones to view instructional video demonstrations facilitate brick laying apprentices to achieve the practical learning outcomes for a module in arch construction and if so, to what degree?" 
The paper will begin by offering some background to the research topic. Following on from this a review of the literature on mLearning applicable to this study is presented. The conceptual framework along with the methodology used for the study is then discussed. Also the methods used for the data analysis including the limitations and delimitations of the study are highlighted. Finally a discussion of the findings, conclusions and recommendations are offered.

\section{Background and Context}

For this mLearning project, initial investigations into this field resulted in the creation of a number of short instructional video demonstrations in early 2009 which were embedded into theory lessons on arch construction, and the benefits of using video demonstrations were evidenced first hand. From this, the idea of transferring and using these video demonstrations in the workshop materialised. All of the apprentice students in this project had mobile phones, but it was not known if they were all capable of playing videos. However a decision was taken to try and utilise these phones which included investigating the video capabilities of the student's own devices. Using the students own phones was an important part of the study, as was adapting a straight forward approach to the development and transfer of the video files. This was to allow future students to avail of these methods of mLearning as well as other teachers.

In 2001 Mark Prensky coined the phrase Digital Natives, suggesting that the youth of today are "Native speakers of the digital language of computers, video games and the Internet" (2001, p.1). Prensky has argued that in the discipline "as educators, we need to be thinking about how to teach both Legacy and Future content in the language of the Digital Natives". He emphasises how hard it is "learning new ways to do old stuff", and makes the point that "we have to invent, but not necessarily from scratch" and adapt materials to the language of the Digital Natives (p.4). This study makes use of the ubiquitous nature of the mobile phone and by having a resource such as video demonstrations available which the students can access in the workshop, it could facilitate just-in-time training.

The project explored phase six of the Irish standards based apprenticeship system. This system was introduced in 1990 and consists of seven phases of training delivered over a four year period. The phases are alternated between on-the-job and off-the-job training with phase six being delivered off-the-job over ten weeks in an Institute of Technology. The intention was to support the learning of phase six apprentice students by investigating whether a selection of videocasts delivered via mLearning facilitated or transformed their learning. This was to address a difficulty identified by the teacher-researcher with the level of practical learning outcomes achieved by bricklaying apprentices on a module in arch construction. More specifically, this difficulty was with setting out, marking, cutting and building bricks for various parts of a 
segmental arch which effect the visual quality of the finished decorative arch. The reasons for these difficulties were as follows:

1. The class size of sixteen students to one teacher decreased the amount of support time a teacher could spend with each individual student and;

2. Allocated face-to-face tutoring time for this module (four weeks) was too short to be effective as there were a large amount of practical techniques and skills to be mastered.

Ideally it was important to decrease the student/teacher ratio for workshop tutoring by providing individual demonstrations for each student, but this was not practical. There are a number of factors to take into consideration: best practice for teaching practical psychomotor skills is through using demonstrations for modelling, drill and practice and rote learning (Toohey, 1999). Cognition and reflection is also required for mastering these skills (as cited in Reece and Walker, 2000). Situated learning is better as it is more authentic for the student (Whitaker, 2005) so demonstrations were needed in the workshop; and as Gray (2009) has identified, bricklaying apprentices are mainly visual learners, so would benefit from seeing live demonstrations.

The idea was to address these issues by creating eleven short instructional video demonstrations, which could be stored and accessed by the students on their own mobile phones, a process similar to what Evans et al. previously suggested (2005) in their "Landscape Study in Wireless and Mobile Learning in the post-16 sector".

The memory cards in the student's phones were utilised for this. Okolo (2006) recommends ideally using short clips five minutes long or less; this is to ensure that:

1. The clips are kept bite size, which will aid students' attention span; and

2. To minimise the size of the video file for transferring and storing.

These videos were created using a Nokia N95 mobile phone which produced good quality up-close demonstrations. Using the phone to take the videos helped, as it could clearly be seen how the finished videos would look on the small screen of other people's phones. These video demonstrations on the student's phones were used in conjunction with the standard group demonstrations and format usually used for delivering each workshop. Therefore a blended approach was taken as recommended by Fill and Ottewill (2006) in their paper on the effectiveness of video streams as learning resources and by Bowman and Kearns (2009) in their report on the impact of eLearning on employability skills development.

\section{Literature Review}

The literature for this study was investigated from a dual perspective: the technological advancements over the past decade which have accelerated the demand for mobile learning among many learners and the pedagogic aspects of mLearning, particularly 
content design, style of presentation and how the technology is used to support communication, collaboration, reflection and feedback in a learning environment.

The majority of the literature investigated for the research emanated from the UK and Australian higher education, with some studies emerging from the USA, Japan and also other European countries. Using mLearning and mobile phones for teaching, learning and training is fairly new, but using video is not. Therefore, the literature search on mLearning only went back approximately seven years whereas the search for video extended to more than twenty. There are many large projects and studies in mLearning which have been carried out in various parts of the world; discussing these in detail however is beyond the scope of this paper. Instead, some of the main issues that have emerged in mLearning research over the past few years which are pertinent to the research objectives of the project will be discussed. The lack of published research in the vocational education sector on mLearning, and also the need for research into the use of the common mobile phone for mLearning was identified. Both of which will be directly addressed within this study.

Vavoula and Sharples (2008) have posited that "Mobile learning is a relatively new research area, with the first research projects appearing in the second half of the 1990s and the first international research conferences less than a decade ago" (p.196). Initially the use of wireless portable computers and laptops were investigated for use in mobile learning. As technology improved PDAs (Personal digital assistants), mobile phones and more recently smart phones which offer similar functions to a PC have taken their place in this area of research. In the UK, the use of mLearning in further education has been identified as a possible way of addressing social issues such as unemployment (MoLeNET, 2009) and as a way of utilising wireless technologies for improving student experience in the post 16 education sector (Kukulska-Hulme et al., 2005). In Australia, mLearning has been identified as a way to address geographical problems as well as pedagogical ones for learning and teaching in addition to training (Drummond, 2007). In developing countries such as Africa, the use of mobile phones to address economic issues surrounding access to education has been studied with Botha et al. (2008) arguing that "the challenge has been to use the unique capabilities of the mobile phone as a technology tool in a pragmatic way" (p.44). In other countries such as China (Huang et al., 2008) and even more so Japan, the widespread ownership of mobile phones over the last number of years is one of the main drivers for research into mLearning (Shudong and Higgins, 2006). It can be claimed that the two main areas of focus in all of this research have been technical and pedagogical.

It has been reported that ubiquitous access to the Internet or lack of access can seriously affect the uptake and success rate of mLearning (Anderson and Blackwood, 2004). Cochrane (2008) makes the point that "previous trials identified the importance of a ubiquitous connection to the Internet for student productivity across multiple contexts and the preference of students and tutors to carry a single device (i.e. a cell phone)" (p.90). In recent times 3G (3rd Generation) phones with Internet access via 
GPRS (General Packet Radio Service) has helped with this problem but this also has limitations and cost factors (Shudong and Higgins, 2006). Other technical issues with mobile devices that have been reported are memory space and speed, including available capabilities in relation to tools and software as well as screen size and resolution (Ahmed Kazi, 2007; Eicker and Matthee, 2008).

Technical issues are dictated mainly by the choice of mobile device. The use of PDAs and some smart phones can overcome some of these problems; however the cost of these devices is a huge inhibiting factor. Traxler (2005) suggests that "support for student and staff members' own devices is one way that institutions can reduce pressure on their own resources" (p.4). Also Gutierrez et al. (2008) suggest that "to develop applications to be currently used by a wide range of users, the target devices must be the mobile phones rather than PDA or bigger devices" (p.1). Shuler (2009) goes further by saying "Relying on features that are more common on less-expensive phones will help ensure that mobile technologies can help close rather than amplify the digital divide" (p.7). This is being addressed through software development and improved capabilities of new phones that can solve these technical problems (Bird and Stubbs, 2008). It is reasonable to conclude that educators and researchers are attempting to find new innovative ways to use mobile devices for learning and teaching. How best to use mLearning from a pedagogical point of view is paramount. Different learning theories and some eLearning theories have been adopted for mLearning, as discussed by a range of researchers in recent years (Siemens, 2004; Naismith et al., 2004; Botha and Ford, 2008). In the past, "the negating of the importance of the pedagogical implications for a mobile learning environment has proven disastrous" (Botha et al., 2008, p.45) and in some cases has lead to "almost total lack of adoption by users" (Er and Kay, 2005, p.322). What is unique about mLearning is the ability for the student to be mobile as highlighted by Kukulska-Hulme (2005) and the potential for the learning to take place in different locations. There is also opportunity for learning to become more personal and more student centred as suggested by Muyinda (2007). Sewell (2008) points out that "the use of these devices to deliver training in the workplace allows pedagogy practices that establish connectedness between theoretical applications and practical tasks, promoting a holistic learning environment” (p.1). This is what this research hoped to achieve through the use of instructional video demonstrations using similar methods to those proposed by Maniar (2008). Muyinda (2007) argues that "the mobile phone has found a place as permanent companion of the poor and the rich" (p.2). For the student however the cost of accessing the Internet via their mobile devices is still high and smart phones are expensive to buy. Preskey (2004) articulates his thoughts on the digital divide: "can cell phones really provide their owners with the knowledge, skills, behaviours, and attitudes that will help them succeed in their schools, their jobs, and their lives? I maintain that the only correct answer to the question of what students can learn with a cell phone is anything, if we educators design it right." (p. 3). 
Pedagogically, there have been significant enhancements of learning and teaching, due to the use of mLearning. Cochrane and Bateman (2010) argue that mobiles have transformed pedagogy and facilitated student engagement and collaboration in a variety of course contexts in tertiary education settings. The data sharing applications of mLearning support communication, collaboration, and knowledge construction, showing that students can consume and create information both "collectively and individually" (Koole, 2009, p. 26).

Laurillard (2007) suggests that the critical pedagogical contribution made by mLearning lies in its learning context. It offers exciting new opportunities for teachers to place learners in challenging active learning environments, making their own contributions, sharing ideas, exploring, investigating, experimenting, discussing, but they cannot be left unguided and unsupported. To obtain the best from the experience, she argues the complexity of the learning design must be rich enough to match those opportunities.

\section{Conceptual Framework}

Fill and Ottewill (2006) reveal that when using video for teaching "it is not enough to leave the learners alone to paddle, sink or swim in the stream" (p.406). Karpinnen (2005) also makes this point as does Laurillard in her seminal work on the use of educational technology in university teaching (1993). To support the integration of the instructional videos for this research study, Laurillard's conversational framework (1993) was used in order to frame the learning scenario for which the videos were used in the workshop (Figure1).

Laurillard uses the framework to describe how learning takes place through using conversation. She suggests that "teaching is a rhetorical activity: it is mediated learning, allowing students to acquire knowledge of someone else's way of experiencing the world" (p.29). The framework is adopted to illustrate this mediation through conversation and reiteration of understandings between the teacher and student. Laurillard also argues that "knowledge must be used in authentic activity in order to form a full understanding of the knowledge and how it operates" (p.17) and this is an important aspect of the framework for this study. The conversational framework was chosen for this study because Laurillard's observation on knowledge acquisition is especially relevant for the context of apprentice learning in this study. It is acknowledged that the original conversational framework is "not normally applicable to learning through experience, nor to 'everyday' learning, nor to those training programs that focus on skills alone, all of which tend to occur at the experiential interactive level only" (p.102). However as mentioned previously, cognition and reflection is also required for mastering these skills (as cited in Reece and Walker, 2000), and Laurillard posits that "cognitive psychologists will argue that experiential learning has adaptive and reflective components as well" (p.102). Of particular interest to this present study is Laurillard's (2007) extension of her framework which can be used to test what this new technology of mLearning contributes to the learning process. She is especially 


\section{Teacher}

Medium

\section{Student}

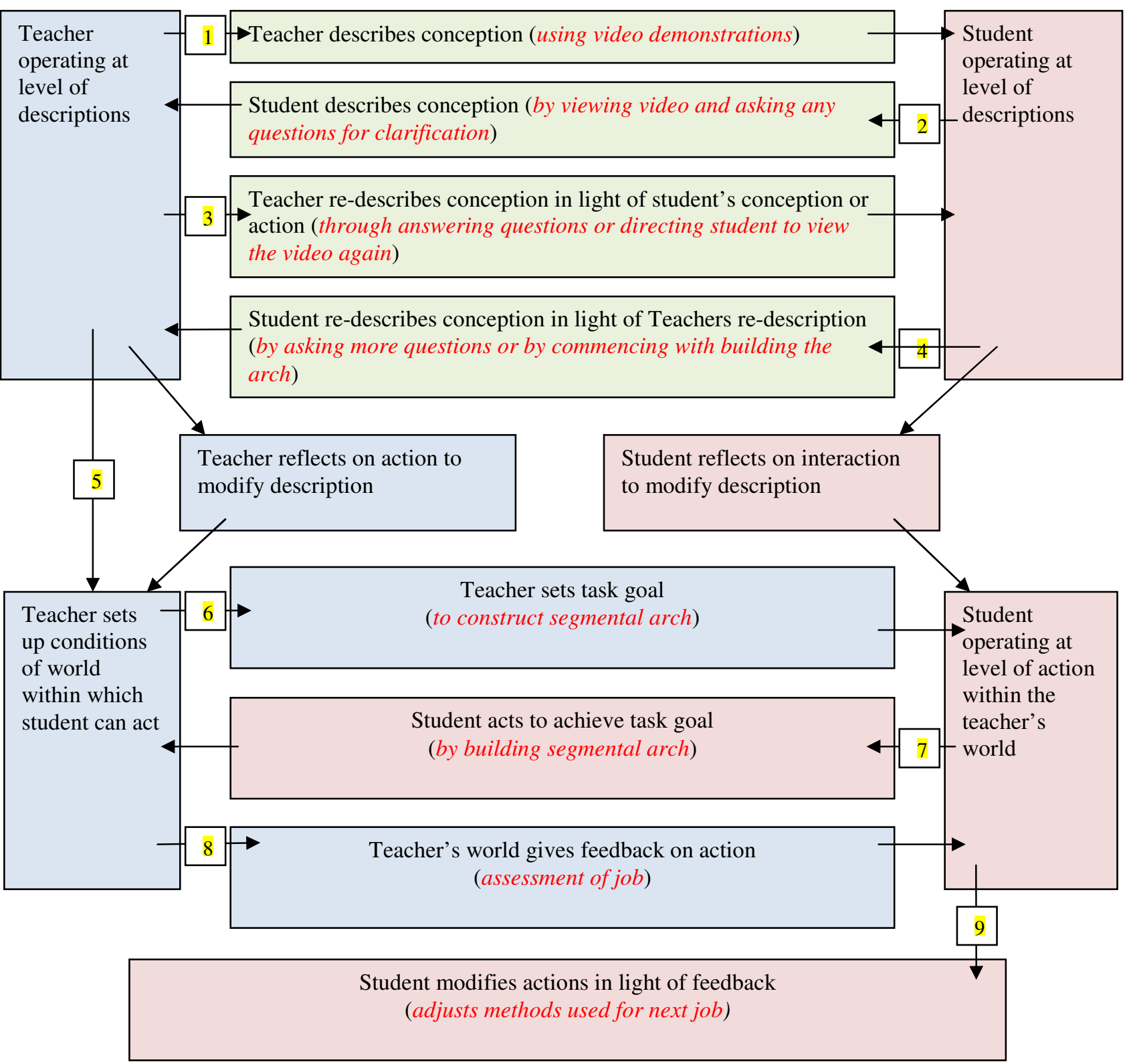

Figure 1 Adapted from Laurillard's Conversational Framework (Hickey, 2010) The information in 'italics' is the author's emphasis

interested in the exploration of mobile learning suggesting new ways of developing the conversational framework.

By following the process outlined in the framework in Figure 1 it is possible to facilitate students to achieve their learning outcomes. There are three main streams presented in this framework: teacher, medium and student. On the left the teacher's actions are illustrated and on the right the students' actions. The centre (the medium) is where the 
interaction between both the teacher and the student takes place, thus the use of "mediated learning" (p. 29). The technology being used for this study are instructional video demonstrations on the mobile phone. Sharples et al. (2006) advocate the use of conversational theory for application within mobile learning. They argue that the use of technology "may provide or enrich the environment in which conversations take place" and that it can also "demonstrate ideas or offer advice at the level of descriptions" (p. 8) similar to the use of video in this study. Laurillard tells us that "sadly, the one-to-one tutorial is rarely feasible as a method in a system of rapid expansion beyond a carefully selected elite, so we look to other methods to provide the same effect more efficiently." (p.97), and this is precisely what this study aimed to do through using videocasts.

It was expected that some of the students in this study would be capable of internal dialogue in order to adapt, reflect and learn whereas some would not and especially within the given timeframe in the workshop. So the conversational framework was used to facilitate the learning cycle within the workshop and optimize the time available for learning. The idea was that students use the instructional video demonstrations on their mobile phones to progress through the various stages of the conversational framework and learn the tasks for building the segmental arch with the support of the teacher-researcher in the workshop.

\section{Methodology}

The research objectives of the study span four key areas for apprentice education in this emerging age of mobile learning: identification of patterns of mobile use, gauging of the appeal of mLearning, ease of usability (which includes technical issues with mLearning) and student's perception of effectiveness of instructional videocasts for learning.

Stenhouse (1975) argued that 'curriculum research and development ought to belong to the teacher' (p.142) and that teachers should research their own practice. Action research did not originate in education but has been used in this area for the past thirty years and was the underpinning methodology used for this study. McNiff (2002, p.2) outlines the process of action research saying "it involves identifying a problematic issue, imagining a possible solution, trying it out, evaluating it (did it work?), and changing practice in the light of the evaluation".

Stage one of the cycle (Figure 2) was the identification of a problem by the teacherresearcher with his own students achieving practical learning outcomes for a module in arch construction.

This problem had existed for many years; however until now the researcher had been unable to find a solution, as the available time for learning in the workshop and the high student teacher ratio was the main cause of the problem. McNiff (2002) articulates that "sometimes we say we believe in something, but are unable to live according to what 


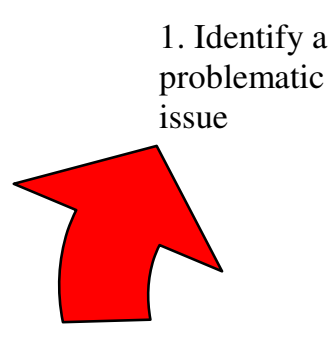

5. Change
your practice
in light of the
evaluation

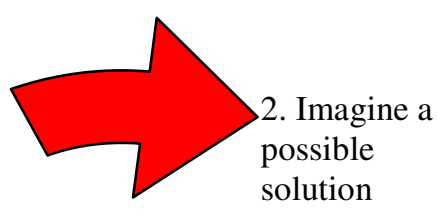

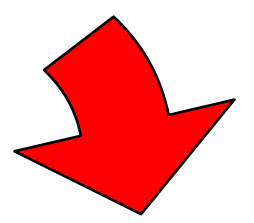

3. Try it out

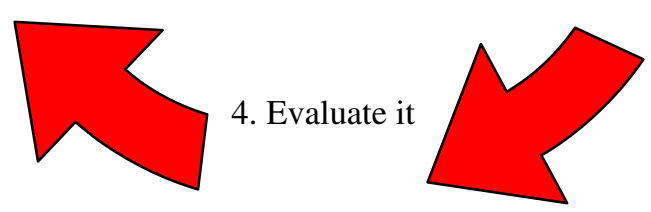

Figure 2 Action Research cycle Mc Niff (2002)

we believe" (p.13). Whitehead (1989) calls this "the experience of holding educational values and the experience of their negation". He describes this as a "living contradiction within the presentation of a claim to educational knowledge" (p.2). According to McNiff, action research is about finding "ways of overcoming the contradiction so that we might live more fully in the direction of our values" (p.13). The researcher believes that providing adequate time and one to one tuition is vital for learning the psycomotor and reflective skills required in order to become a successful craftsperson. Therefore as a teacher, being able to move closer to his beliefs will allow the researcher to live more fully in the direction of his educational values.

Stage two of the cycle was imagining the possible solution, which was the students using instructional videos on their own mobile phones. For the purpose of the study and the creation of the videos, a decision was made to focus on one of the main arches to be built in the workshop. The skills required to build this particular type of arch (Axed Segmental) would be transferable and could be used for building many other types of arches. A detailed schedule of the tasks and skills needed to construct the arch were drawn up in a logical sequence. These were then broken into manageable chunks of learning, titled to aid access and a plan and script was formulated for each of the eleven videos. The videos consisted of live demonstrations recorded in the workshop of the researcher carrying out and explaining the tasks and skills to be used at each stage of the building process.

Stage three was to implement the plan. One class (sixteen students) of fourth year apprentice bricklayers took part in the study. Over the past five years, an average of one hundred and sixty apprentice bricklaying students were registered annually in 
Ireland, so this sample represents approximately ten percent. Over the ten week period of phase 6 of an apprenticeship in brick and stone laying in January 2010, the following project was carried out. In week one the students were provided with an overview of the research project, with emphasis placed on contextualising it and presenting a clear rational for them. From an ethical perspective, the students' agreement to participate in the study was sought. An ethics statement highlighting the importance of confidentiality and anonymity was drawn up and distributed and a statement of informed consent completed by each student. Technical information was obtained about students' phones by asking them to fill out an information sheet. At this stage it was identified that all sixteen students' phones had the capacity to take a memory card and play videos, but nine students did not have a memory card in their phone. Subsequently nine 1 gigabyte micro SD memory cards were purchased by the teacher-researcher at a cost of $€ 10$ per card and these were distributed to the students. The eleven videocast demonstrations were placed on the memory cards of the student's phones using a multi card reader. They were then given an overview of the demonstrations and directions on how to use them, including several trouble-shooting sessions. During week two and three the students were directed and guided to use the video demonstrations on their phones while building the segmental arch in the workshop.

Stage four was to evaluate the study using a combination of:

1. A survey questionnaire completed by each student;

2. A practical assessment of each job by the researcher;

3. A focus group interview with several of the students from the group; and

4. Observations by the researcher through keeping a research diary.

\section{Methods}

In week four a questionnaire was distributed to all sixteen students to ascertain their experiences of using the videos. Prior to this during week three each student's completed job was marked using a practical assessment sheet which was designed to evaluate specifically the practical learning outcomes addressed in this study. It was used in conjunction with the questionnaire to explore if there was any link between the use of the videos and the level of the practical learning outcomes achieved by each student. A researcher diary was kept throughout the duration of the project which helped to inform the findings of the study from the teacher-researcher's perspective.

Based on an initial analysis of the data collected in weeks three and four from the questionnaire, practical assessment and a researcher diary, a focus group interview was held with five students. In order to form a fairly homogeneous group, the students were selected on the basis of certain characteristics such as ability and their attitude to learning in the workshop. It was also important to select students who had mobile 
phones of varied quality. The interview was used to explore the students' perception and experience of how effective the videos were for learning including the specific ways they found them effective. It was chosen as a method to gain insights into the students' shared understandings of the videocasts and mLearning. The interview was video recorded to aid analysis.

The questionnaire addressed four key topics:

1. Patterns of mobile use;

2. Appeal of mLearning;

3. Ease of usability including technical issues and

4. Perceived effectiveness of instructional videos for learning

Closed questions with an option to make comments were used and a Likert type scale was included for ranking questions (Likert, 1932). A Likert scale usually has five or seven possible responses; however for this questionnaire only four responses were offered for each question which is sometimes referred to as a forced scale. This was to allow each student to give a definitive answer to each question and to avoid a large amount of "uncertain" responses. The questionnaire focused on establishing student preferences on mLearning delivery of their phase six instruction. Questions were constructed on the following:

1. If the students used the videos how often did they access them and from where?

2. Did the students prefer the video demonstrations over group demonstrations in class? Would they like more of them? Would they use them on site?

3. Did the students have any technical difficulties (battery life, video formats, storage capacity, visual- size of screen, clarity, distance of demonstration from camera, audio- clarity and volume). Could they offer any suggestions or recommendations for technical improvements?

4. Did the students find the videos useful/helpful for learning? How did the students perceive and rate the effectiveness of the videos for learning this subject?

\section{Data Analysis}

Creswell (1994) suggests that triangulation can help avoid any bias in the research process. A variety of methods were used for collecting the data for this research including a review of the current literature in the field. The data for the study was analysed by following Miles and Huberman's (1994) interactive model of data analysis (Figure 3). 


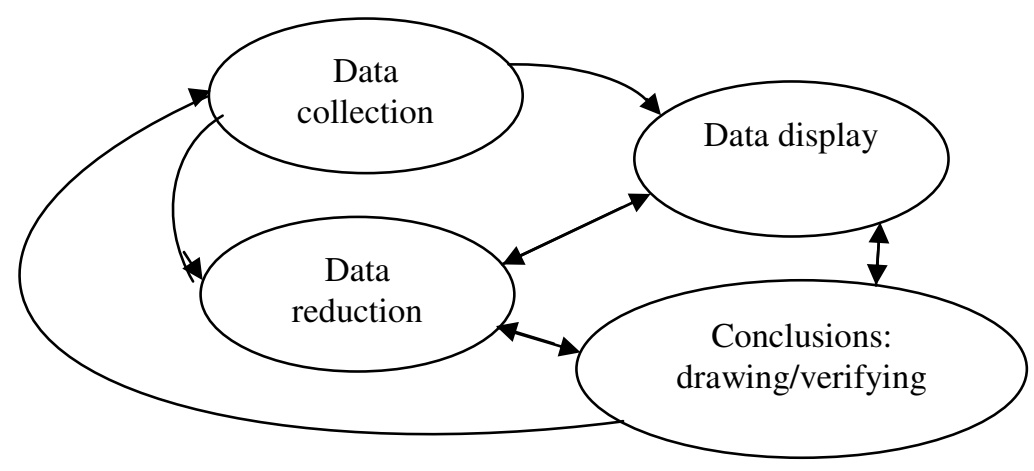

Figure 3 Miles and Huberman's interactive model of data analysis (1994, p.12)

They also suggest using a variety of methods for data collection along with implementing a continual cycle of reduction and display in order to draw and verify conclusions from the dataset. A series of apriori codes were defined primarily through the design of the survey questionnaire which identified four key areas for investigation: patterns of mobile use, appeal of mLearning, ease of usability (which included technical issues) and students' perception of

effectiveness of videos for learning. Other empirical codes were also identified during the analysis process. Each question contained in the questionnaire was coded as was each part of the practical assessment sheet. From this, graphs and charts were generated to assist analysing and presenting the findings of the study.

The findings from the focus group interview were examined and cross referenced with the questionnaire and practical assessment results to ensure the validity of the findings. Entries in the research diary gave the teacher-researcher's perspective within this cycle of the action research and were used in conjunction with all of the other data collected to draw the final conclusions for the study.

\section{Findings and Discussion}

There are five main themes presented in this section of the paper. The first four were drawn from the initial apriori codes defined through the design of the survey questionnaire and the fifth is based upon the improved teaching and learning methods experienced by the participants of this study.

\section{Patterns of use}

Results from the questionnaire showed that $75 \%$ of the students viewed the videos both at home and in the workshop on their mobile phones. Fifty five percent (55\%) watched them before they built the arch and $80 \%$ watched them while building the arch. Only one student watched the videos while travelling to college. Eighty percent $(80 \%)$ watched them at least twice and $25 \%$ more than twice. All of the students viewed the videos by themselves. It was noted by the researcher during the study that all but one student viewed the videos while building the arch in the workshop. A 
correlation was noted between the patterns of use and the results of the practical assessment (see Table 1). The one student who did not use the videos at all (student 8), but who still thought they were a good resource, scored $94 \%$ in the assessment which was fourth highest in the class (see Table 1). This particular student had prior experience of building this type of arch out in the workplace and felt he did not need to look at all of the videos. All of the students were encouraged to view the videos but were not forced to use them. If (student 8 ) had viewed all of the videos he may have been able to improve his score. The student who did score the highest in the class $98 \%$ was one of the students who viewed the videos the most amount of times (4), and did so in order to gain a thorough understanding of the tasks. He said " having control of when and where to view the demonstrations and being able to look at them again and again was great" (student 10). Three other students viewed the videos more than twice, and it was noted by the researcher that in the workshop they were three of the weakest students. Nevertheless they scored between $60 \%-75 \%$ and every $5 \%$ loss in the overall result was equivalent to only one millimetre of inaccuracy so even these results reflected a very high standard of workmanship. They also viewed the videos repeatedly in order to gain a more thorough understanding of the tasks. They commented on the availability of the videos saying "I think the videos are a very good source of learning for what to do while building an arch" (student 11) and that "I tend to forget instructions very quick, therefore the videos were very helpful!!" (student 13).

In Romanov \& Nevgi's (2007) paper on medical students use of video clips to facilitate learning, they reported that students who watched the video clips achieved higher course grades. Similar findings can be drawn from this study. Although it was not a comparative study and thus there are no statistics to show this, it was a study driven by the researcher's wish to improve his teaching practice and subsequently the level of learning outcomes being achieved by the students. It was noted during the study by the teacher that the high results and the quality of the practical learning outcomes achieved by all of the students exceeded any of the previous groups who completed this practical exercise. It is also fair to say that both the stronger and the weaker students found the videos effective for supporting their learning.

Table 1: List of Students Practical Results and the Phones used in the study

\begin{tabular}{|c|c|c|c|c|c|c|c|}
\hline Student & $\begin{array}{l}\text { Viewed } \\
\text { Videos }\end{array}$ & $\begin{array}{l}\text { Result } \\
\%\end{array}$ & $\begin{array}{l}\text { Phone Brand } \\
\text { and Make }\end{array}$ & Student & $\begin{array}{l}\text { Viewed } \\
\text { Videos }\end{array}$ & $\begin{array}{l}\text { Result } \\
\%\end{array}$ & $\begin{array}{l}\text { Phone Brand and } \\
\text { Make }\end{array}$ \\
\hline No 1 & 2 & 91 & Nokia E51 & No 9 & 2 & 97 & $\begin{array}{l}\text { Samsung Tocco } \\
\text { Lite }\end{array}$ \\
\hline No 2 & 2 & 86 & $\begin{array}{l}\text { Nokia } 3120 \\
\text { Classic }\end{array}$ & No 10 & (4) & (98) & $\begin{array}{l}\text { Samsung } \\
\text { GT55230 }\end{array}$ \\
\hline No 3 & (3) & (72) & $\begin{array}{l}\text { Sony Ericsson } \\
\text { W200i }\end{array}$ & No 11 & (3) & (76) & Samsung B2100 \\
\hline No 4 & 2 & 76 & Sony Ericsson & No 12 & 1 & 82 & Semobi (Chinese) \\
\hline No 5 & 2 & 92 & Nokia 5310 & No 13 & (5) & (62) & $\begin{array}{l}\text { Samsung Tocco } \\
\text { Lite }\end{array}$ \\
\hline No 6 & 2 & 84 & Nokia 5530 & No 14 & 1 & 58 & Sony W320 \\
\hline No 7 & 2 & 88 & Samsung Tocco & No 15 & 2 & 82 & $L G$ iso 800 \\
\hline No 8 & (0) & (94) & Nokia E51 & No 16 & 2 & 96 & LG Cookie \\
\hline
\end{tabular}




\section{Appeal of mLearning}

It was identified that $70 \%$ of the students liked using their phones for viewing the demonstrations and the other $30 \%$ really liked using them. Fifty percent (50\%) liked being able to view the videos at a time and place that suited them and being able to view them more than once. The other $50 \%$ really liked these aspects of mLearning. All of the students wanted more of these demonstrations on their phones for other jobs, a point which was brought up again and again in the focus group interview. The students said they would not just like demonstrations for the other practical jobs in phase six but for many other different types of practical and technical skills needed in their trade. Ninety percent $(90 \%)$ of them said they would like to use these types of video demonstrations out on site. This point was reinforced in the interview where the students gave examples of how the videos for this study and other possible videos could be of benefit to them throughout their working lives. Only $50 \%$ of the students agreed that they preferred the video demonstrations over the live ones. Forty five percent $(45 \%)$ disagreed with this with $5 \%$ strongly disagreeing. One student who disagreed said "Sometimes you can't ask the videos questions but they did help a lot" (student 15). However through the interview and in the written comments on the questionnaire they expressed a need for both, saying "It's good to have both and then if you get stuck you have your phone to fall back on and look" (student 3). Macurik et al. had similar findings in their study on video training in comparison with live training stating that "responses on the Likert questionnaire indicated that overall both types of training were rated favourably by staff" (2008 p.156). The ability for each student to view these videos as often and when they needed them would have been imposable within the workshop setting without the use of a mobile device. Therefore the familiarity the students had with their own devices played a crucial role in this study as did the use of the memory card on each phone.

\section{Ease of usability including technical issues}

The main technical issue that emerged in this study centred on the maximum bite rate and resolution of the video files supported by each type of phone. There were sixteen students and five different brands of phone used in this study with thirteen different types of phone. One of the aims of the study was to try and utilise today's standard mobile phone for teaching and learning. This was to allow access to this type of learning for as many students and teachers as possible. Through investigation and experimentation the researcher identified a standard video file format; bite rate and resolution that could be supported by all of the phones used in this study (see Table 1). Also important is the specific video file format converter used to convert these files to the correct format and bite rate. All of the original video files were MP4 in format and had bit rates as high as 2500/second. As part of the emphasis of the study was on ease of use for other staff to implement the technology, a free downloader and converter was used. It was obtained from http://youtubedownload.altervista.org/. Once a file is selected to be converted and the output file type has been set to 3GP a popup 
appears which gives an option to select the quality of the output file. The "optimal" output should be selected with the sound quality set at its highest. This will produce a file format of 3GP with a resolution of $176 \times 144$ and a maximum bit rate of $162 /$ second. This is the standard file type which has been identified in this study to be supported by all of the standard mobile phones used by the sixteen students. Some of the phones may support higher bit rates and resolutions however the improved finished quality of the video will only be noticeable if the bit rate and resolutions are greatly increased. Therefore files that are converted to 3GP with a maximum bite rate of 162 and resolution of $176 \times 144$ using the "optimal" visual setting and maximum audio setting with this specific YouTube file format converter, will give good quality videos which can be supported and played on all of the standard phones listed in Table 1.

From the perspective of access $85 \%$ of the students found it easy to access the videos on their phones. The $15 \%$ who found it difficult were the students whose phones could not initially support the file format i.e. the bit rate was too high for the phones, but this was rectified once the bit rate was reduced to the 162/second. However it took some time to identify and resolve this specific problem and it was half way through the study before it was rectified. Forty per cent (40\%) of the students said they had difficulty with viewing the videos on the small screen saying "Some instructions were not as clear with the small screen" (student 13). When the students were asked in the interview if they had any suggestions for improving the content or the delivery of the videos, the small screen size was identified as being the only real problem. The students did recognise that this was dictated by their own personal device and as one student said "sure that's our problem not anyone else's" (student 3). This issue had been identified in the past by Maniar (2008) in his research on the effect of mobile phone screen size on video based learning. He identified that students viewing videos on smaller screens learnt a significantly lower amount. Nevertheless $95 \%$ of the students in this study found the picture quality of the videos good and the student who did have a problem said "the phone I have is old and it was hard to see, but on other phones it was perfect" (student 3). Similar to Maniar's research, this study found that all of the students had a positive overall opinion of mLearning. In their study on challenges encountered in secondary school mobile learning environments Eicker and Matthee said that "learners have indicated that their perception of mobile learning's usefulness is influenced by the availability of quality video" (2008, p.142). The high level of satisfaction with the picture quality and the perceived effectiveness of this type of mobile learning found in this study correspond with Eicker and Matthee's findings.

In audio terms $75 \%$ of the students said they found it easy to hear the videos on their phones. Two students said they did find it difficult to hear the videos in the noisy workshop environment. Another student had a broken speaker and another said his phone was old but "he could hear them perfect on other people's phones" (student 3). None of the students had any problems with the battery life on their phones when viewing the videos or any problems with the storage space taken up by the videos. 
This was probably due to the short duration and size of each video, which were only two to four minutes in length, and one to three megabytes in size. All but one student found the up close method used for filming the demonstrations very effective. These specific methods used for filming with the mobile phones were taken from the Turning Point project on engaging youth in mobile learning, where Drummond suggests to "use close up shots, use minimal panning, overstate content, use strong lighting, use slow movements" (2007, p.10). The one student who was discontent said he would have liked some parts of the video zoomed in closer so he could see the millimetre perfect details required for all of the cuts (student 2 ).

\section{Perceived effectiveness for learning}

In the questionnaire all of the students said the videos clearly showed them how to carry out the different tasks for building the arch. They found them effective for learning how to build the arch and thought the number of videos and the amount of detail in the demonstrations effective for learning the skills required. They all said that being able to view the demonstrations more than once helped to reinforce their learning and that viewing the videos helped them to build the arch correctly. Fifty percent $(50 \%)$ agreed with all of these statements and $50 \%$ strongly agreed. The high standards achieved and noted in the practical assessments for this study (see Table 1) are in line with these findings. The evidence from the researcher's observations and the interview with the students show that they used the videos to go through the various stages of the conversational framework in order to help them learn the tasks and they applied this learning to achieve the practical learning outcomes for the module. The videos played an important part in facilitating the students' learning. It saved time as the teacher did not have to go through the lengthy process of carrying out the same demonstrations with each individual student. Therefore because the students had access to this learning material it freed up the teacher to focus more on specific individual student needs in the time available. So from the teacher's perspective it has helped to improve his practice. The videos have given the students and the teacher something they would both not have had otherwise, which is extra time in class and learning resources. Therefore this method of teaching and learning is an improvement on the researcher's previous practice, as the learning material was covered in a more thorough and detailed way than was possible before. It was noted in the researcher diary, that due to the extra learning material available to the students in the workshop via mLearning, a deeper and broader level of learning was evident than had been observed with previous groups of students who had taken this module. These previous observations by the teacher were the catalyst for this study, as the learning outcomes were not being met by all of the students. The students were exposed to more tuition through the use of the videos not just directly but by seeing their peers using the videos they became more aware of the material and of its importance. 


\section{Improved teaching and learning}

The findings from this study indicate student engagement and appreciation of mobile technologies to aid their learning. It is clear from the findings that this method of mLearning was student centred and allowed the students as stated by O'Neill and McMahon (2005) to have more control over their own learning. The five students themselves said in the interview that it allowed them to "work away on their own" and they did not have to keep on waiting for the teacher to be free; one student said "you can watch it over and over yourself again and get it into your own way of thinking and once you have it figured out yourself then it's helpful that way" (student 5). Another student said "I like figuring things out for myself and learning from my mistakes so it was good to have the control" (student 10). The practical orientation of the videos made the learning more authentic which was evident in the interview when the students said that the video they found the least helpful was the Arch Terms, which was a recording of a power point presentation. One student said "it's better to watch you doing it then looking at what's written" (student 4). A different student also said "it would have been better on the real arch" (student 5). All five students in the focus group agreed that this was the least helpful video and they showed much more interest in viewing and using the live video demonstrations. This was the first of the eleven videos and was essential to the study as it explained the seventeen arch terms which would be referred to continuously throughout the recorded live demonstrations.

Using the mobile phones to view the videos helped to create new opportunities for the students to learn in the workshop space. As there is only one teacher to sixteen students and contact time is limited, this dictated the pace of learning in the workshop, but this was overcome by using this blended approach. All of the students in the interview agreed that using the videos did not just save them time but in fact created more time for learning; "Well I suppose you can say that it kind of speeded everything up. You would be going around everyone, showing people other things and so I wouldn't have to wait for you to finish with them; it was much better being able to go and watch it myself on my phone and then view it again. So there was no standing around" (student 1). This is very similar to just in time training as the students could access the information on the spot as they needed it, as pointed out by Anderson and Blackwood (2004), Muyinda (2007) and Sewell (2008). One student commented "When stuck all I had to do was look at my phone!" (student 6) and another said "I could watch them as I was building the job and I always knew what to do next and how to do it" (student 1). At one level, this might suggest that this student was replicating rather than understanding the process; however arguably they are not missing out on the cognitive element of the psychomotor skill development as they are now operating in a mixed environment for learning which is providing on-demand learning opportunities with more objective, detailed feedback than available with expert observation alone. Student 1 showed his understanding of both the material and his use of this mLearning resource commenting "I messed up my bird's mouth twice, and then I watched the video and got them perfect" (student 1). Cutting and building the 
'birds mouth' accurately on an axed segmental arch is not achieved by simple replication. In the interview one student also said “you don't have to drop down your trowel or anything; you know what I mean like you can just take out your phone and stay in the same square you are building in" (student 4).

During the focus group interview some of the students pointed out that having to ask the same questions repeatedly made them feel self conscious, so being able to use the phone to work through their ideas and thoughts made them feel more relaxed and confident. They said using the video in the workshop "helps you to figure it out yourself" (student 5) and "you know how you are going wrong with the video" (student 3) and "instead of keeping repeating the questions to one of the instructors or whatever you can kind of do it yourself" (student 2). They expanded on this by saying "You can interpret it into your own words not just the way it's on the video that is you can put it into your own way of thinking" (student 3) and "you know sometimes it just doesn't click with you, and you can watch it as many times as you want until it does click with you" (student 1).

Laurillard (2002) talks about transformation of information for creating knowledge and it would appear that in part this is the process that the students were describing here. As they went through the steps of viewing the video demonstration on their phones to aid them build the arch, this helped them engage in the cognitive process required for learning how best to build the arch for themselves. Although the support of the teacher was there, the idea was that the students used the videos to go through the various stages of the conversational framework with the teacher to help them learn the tasks. It would appear that the students used the videos to generate an internal dialogue which is better than having to engage with the teacher as this gave the students ownership of the learning (Duffy and Kirkley, 2004). Most of the conversations between the teacher and the students focused more on individual general craft skills issues, and very few discussions were based on the videos. This could be due to the clear and concise nature of the video demonstrations. As one student said in the interview "it was just nice and slow, every single step that you do was shown on the video, so I think all the content and the way they were put was spot on" (student 3). It is very important to note that if it were not for the videos the teacher would not have had time for the individual conversations with the students, which were very important for the development of each student's general craft skills which are interwoven with the practical learning outcomes for this module.

The use of Laurillard's framework in this study was important as it clearly outlined the conversational process required in order for the students to achieve their learning outcomes. Although in this case it materialised that the conversational process for the students was mostly an internal one which was facilitated through the use of their mobile phones and the instructional videos. The important thing is that they did progress through the various stages of the framework and achieved their learning outcomes, and as previously mentioned, Sharples et al. (2006) argue that technology 
"may provide or enrich the environment in which conversations take place". Therefore it is argued that the conversational framework was effective for framing the learning scenario in the workshop.

\section{Limitations and Delimitations}

This study only investigated the use of videos on mobile phones rather than on a range of mLearning applications in a small scale study with sixteen apprentice students. Due to the need for maintaining a pragmatic approach to the project, there was no use of wifi or internet connections for streaming of videos or any other type of learning media or materials. Each student viewed the instructional videos on their own mobile phones which may have had different capabilities. Therefore the quality of the video resource might have differed for each student. Accessibility was a major concern as some student's phones may not have been suitable for the study. The sample videos to be used covered only a small skill set of one practical exercise, an axed segmental arch. This skill set is one of the most difficult to master in the entire ten week course and therefore provided a good gauged sample for the rest of the practical exercises. The timescale for the study was limited as the segmental arch was the first practical exercise of the course, and the researcher had no access to the students before the study commenced. Therefore there was very little time prior to the study for obtaining information on the capabilities of the student's phones and for informing the students' of the aims and objectives of the research. Consequently the study and most of its data collection were completed within the first five weeks of the ten week course.

\section{Conclusions and Recommendations}

This study explored the development of an innovative, student-centred way of improving the learning and teaching experience within the constraints of time and workshop space. It made use of an existing facility and technology that most of today's students own themselves and of which they are familiar, which are mobile phones with video capability. It looked at utilising the memory card space on student phones and establishing the appropriate video formats supported by these phones along with reliable methods of transferring video files onto them. Sixteen fourth year apprentice bricklayers took part in the study to address a problem identified by the researcher with his own students achieving practical learning outcomes for a module in arch construction. Eleven instructional video demonstrations were created to investigate whether using mLearning could be a solution to this problem.

The study showed that the students viewed the videos both at home and in the workshop, and that both the stronger and the weaker students found them effective for supporting their learning. The students expressed an equal need for both the videos and the live demonstrations in the workshop but expressed a high level of satisfaction with all aspects of the mLearning approach. More than $90 \%$ of the students wanted to utilise this method of learning on site in the future. The small screen size was identified 
as being the only real technical problem, yet $95 \%$ of the students found the picture quality of the videos good. It was identified that video files that are converted to 3GP with a maximum bite rate of 162 and resolution of 176 X 144 using the "optimal" visual setting and maximum audio setting with this specific file format converter obtained from http://youtubedownload.altervista.org, will give good quality videos which can be supported and played on all of the standard phones listed in Table 1.

This action research study helped create a richer learning experience for these apprentice students, and made their learning further student centred by focusing more on the individual. It situated the learning 'on the ground' in the workshop and provided just in time training on a one to one basis, thus allowing the student to progress at their own pace and allowed the teacher to focus more on specific individual student needs in the time available. To see the inadequacies of the previous workshop format, one only needed to apply the dual problematics of time constraints and high student numbers: the difficulties of reaching deep knowledge of the subject matter, the fact that the format was inattentive to the apprentice students' individual interests, and at times, this left them disconnected from specific workplace practices and isolated from ongoing support by teachers. Such activities are often the antithesis of what is known to promote effective learning. The study showed that the use of mLearning facilitated both the students and the teacher to overcome these issues of time limitations and high student/teacher ratios.

It is the researcher's intention to carry out further cycles of this study which will expand on the use of instructional video demonstrations for all of the practical exercises in phase six. Now that the researcher has moved closer to living more fully in the direction of his educational values as Mc Niff (2002) highlights it would be difficult to remain static in this area. Further qualitative research is required to explore and investigate students' perceived effectiveness of using this type of video based mLearning. Also from a technical point of view further investigation into improving the quality of the videos to be used on standard mobile phones would be worthwhile. The methods outlined in this paper are transferable to other trades and probably to other areas of third level education in general. Therefore it is suggested that an examination of these methods applied in other trades would be beneficial for achieving findings that could be more generalised. A further rich area for future exploration is the potential to expand this current research to the on the job phases of the apprenticeship system and beyond.

Nowadays in apprenticeship education, with its shifting emphasis on student learning, lecturers are asked to engage their students, to be reflective about their own practice, to integrate evidence of their students' learning and to actively work with colleagues to continually re-examine their practice and the curriculum. This study on mobile learning is an attempt at providing a scaffold and support mechanism for the apprentice students of today in order to make a difference in both the teacher's practice and significantly in the learning experiences of their students. 


\section{References}

Ahmed Kazi, S. (2007). MILE: Mobile intelligent learning environment- A conceptual framework for mLearning. International Journal of Engineering Education, 23 (3), 468473.

Anderson, P., \& Blackwood, A. (2004). Mobile and PDA technologies and their future use in education. JISC Technology and Standards Watch: 04-03. URL: http://www.jisc.ac.uk/media/documents/techwatch/acf11b0.pdf (accessed 2nd May d2009).

Arrigo, M., Gentile, M., Seta, L., Fulantelli, G., Giuseppe, O., Taibi, D., \& Novara, G. (2008). Some considerations on a mobile learning experience in a secondary school. Proceedings of the mLearning Conference, Wolverhampton: University of Wolverhampton Technology Centre. p.20-27. URL:

http://www.scit.wlv.ac.uk/brendan/mLearn2008.pdf (accessed 10th May 2010).

Barford, J., \& Weston, C. (1997). The use of video as a teaching resource in a new university. British Journal of Educational Technology, 28 (1), 40-50.

Bird, P., \& Stubbs, M. (2008). A bridge too far?-embedding mobile learning in UK higher education. Proceedings of the mLearning Conference, Wolverhampton: University of Wolverhampton Technology Centre. p.36-43. URL: http://www.scit.wlv.ac.uk/brendan/mLearn2008.pdf (accessed 10th May 2009).

Botha, A., Traxler, J., \& Ford, M. (2008). MobiLED: A tool by any other name...Proceedings of the $m L$ earning Conference, Wolverhampton: University Wolverhampton Technology Centre. p.44-50. URL:

http://www.scit.wlv.ac.uk/brendan/mLearn2008.pdf (accessed 10th May 2009).

Botha, A., \& Ford, M. (2008). "Digital life skills" for the young and mobile "digital citizens". Proceedings of the mLearning Conference, Wolverhampton: University of Wolverhampton Technology Centre. p.51-57. URL:

http://www.scit.wlv.ac.uk/brendan/mLearn2008.pdf (accessed 10th May 2009).

Bownam, K., \& Kearns, P. (2009). Australian flexible learning framework. The impact of e-learning on employability skills development. Final Report. URL:

http://www.flexiblelearning.net.au/flx/webdav/site/flxsite/shared/Benchmarking\%20and \%20Research/E-learning Employability Report.pdf (accessed 3rd March 2010).

Brett, P. (2008). Mobiles enhancing learning and support. JISC Final Report. URL: http://www.jisc.ac.uk/media/documents/programmes/elearninginnovation/melasfinalrep ort.pdf (accessed 1st May 2009).

Cochrane, T. (2008). Designing mobile learning environments: mobile trails at Unitec 2008. Proceedings of the mLearning Conference, Wolverhampton: University of Wolverhampton Technology Centre. p.89-96. URL: http://www.scit.wlv.ac.uk/brendan/mLearn2008.pdf (accessed 10th May 2009). 
Cochrane, T., \& Bateman, R. (2010). Smartphones give you wings: Pedagogical affordances of mobile Web 2.0. Australasian Journal of Educational Technology, 26 (1), 1-14.

Creswell, W.J. (1994). Research design, qualitative and quantitative approached. London: Sage Publications.

Drummond, S. (2007). New practices in flexible learning. Turning Point: engaging youth in mobile learning. Australian Flexible Learning Framework. URL:

http://turningpoint.flexiblelearning.net.au/tp/pdf/EXTERNAL547 Final report 2007.pdf (accessed 2nd May 2009).

Duffy, T.M,. \& Kirkley, J.M. (2004). Learner-centred theory and practice in distance education. New Jersey: Lawrence Erlbaum Associates, Inc.

Eicker, S., \& Matthee, M. (2008). Obstacles and challenges encountered in South African secondary school mobile learning environments. Proceedings of the mLearning Conference, Wolverhampton: University of Wolverhampton Technology centre. p.137144. URL: http://www.scit.wlv.ac.uk/brendan/mLearn2008.pdf (accessed 25th May 2009).

Ellington, H., Percival, F., \& Race, P. (1993). Handbook of educational technology (3rd ed.). London: Kogan Page.

Er, M., \& Kay, R. (2005). Mobile technology adoption for mobile information systems: An activity theory perspective. Proceedings of International Conference on Mobile Business, Sydney: University Trier, Sydney, Australia. p.322-325. URL: http://www.informatik.unitrier.de/ ley/db/conf/icmb/icmb2005.html (accessed 15th May 2009).

Evans, D. (2005). Potential uses of wireless and mobile learning. Landscape study in wireless and mobile learning in the post-16 sector. JISC. URL:

http://www.jisc.ac.uk/whatwedo/programmes/elearninginnovation/outcomes.aspx (accessed 17th May 2009).

Fill, K., \& Ottewill, R. (2006). Sink or swim: taking advantage of developments in video streaming. Innovations in Education and Teaching International, 43 (4), 397-408. URL: http://dx.doi.org/10.1080/14703290600974008 (accessed 23rd December 2008).

Gray, G. (2009). Learning styles. National learning network. Available on request from Geraldine.gray@itb.ie: Unpublished report.

Gutierrez, J. et al (2008). M-learning enhancement using 3D worlds. International Journal of Engineering Education, 24 (1), 56-61.

Huang, Y-M. et al (2008). Toward interactive mobile synchronous learning environment with context-awareness services. Computers and Education, 51, 1205-1226. 
Karpinnen, P. (2005). Meaningful learning with digital and online videos: Theoretical perspectives. Journal of the Association for the Advancement of Computing in Education, 13 (3), 233-250.

Koole, M. L. (2009). A model for framing mobile learning. In M. Ally (Ed.), Mobile learning: Transforming the delivery of education and training (pp. 25-47). Edmonton, AB: AU Press, Athabasca University.

Kukulska-Hulme, A. (2005). Current uses of wireless and mobile learning. Landscape study in wireless and mobile learning in the post-16 sector. JISC. URL: http://www.jisc.ac.uk/whatwedo/programmes/elearninginnovation/outcomes.aspx (accessed 17th May 2009).

Kukulska-Hulme, A., Evans, D., \& Traxler, J. (2005). Landscape study in wireless and mobile learning in the post-16 sector. JISC. URL:

http://www.jisc.ac.uk/whatwedo/programmes/elearninginnovation/outcomes.aspx (accessed 17th May 2009).

Laurillard, D. (1993). Rethinking university teaching. A framework for the effective use of educational technology. London: Routledge.

Laurillard, D. (2002). Rethinking university teaching. A framework for the effective use of educational technology (2nd ed.). London: RoutledgeFalmer.

Laurillard, D. (2007), Pedagogical forms for mobile learning. In N. Pachler (ed) Mobile Learning: towards a research agenda. London: WLE Centre, loE. http://eprints.ioe.ac.uk/627/1/Mobile C6 Laurillard.pdf (accessed 7th October 2011).

Likert, R. (1932). A technique for the measurement of attitudes. Archives of Psychology, 140, 1-55.

Macurik, K., O'Kane, N., Malanga, P., \& Reid, H. (2008). Video training of support staff in intervention plans for challenging behavior: Comparison with live training. Wileylinterscience, 23, 143-163.

Maier, P., \& Warren, A. (2000). Integrating technology in learning and teaching. London: Kogan Page.

Maniar, N. (2008). The effect of mobile phone screen size on video based learning. Journal of Software, 3 (4), 51-61. URL:

http://www.academypublisher.com/jsw/vol03/no04/jsw03045161.pdf (accessed 5th May 2009).

McNiff, J. (2002). Action research for professional development. Concise advice for new action researchers. Website. URL: http://www.jeanmcniff.com/booklet1.html (accessed 19th November 2009). 
Miles, M., \& Huberman, A. (1994). Qualitative data analysis: an expanded sourcebook (2nd ed.). London: Sage Publications.

MoLeNET, (2009). Mobile learning network. Learning and Skills Council. URL: http://www.molenet.org.uk/events/ (accessed 6th May 2009).

Muyinda, P. (2007). MLearning: pedagogical, technical and organisational hypes and realities. Campus-wide Information Systems, 24 (2), 97-104. URL:

http://www.emeraldinsight.com/Insight/viewPDF.jsp?contentType=Article\&Filename=ht ml/Output/Published/EmeraldFullTextArticle/Pdf/1650240202.pdf (accessed 14th May 2009).

Naismith, L., Lonsdale, P., Vavoula, G., \& Sharples, M. (2004). Literature review in mobile technologies and learning. NESTA Futurelab Series. URL:

http://external.portal.Isri.nottingham.ac.uk/Docs/Documents/Naismith\%20L.,\%20Lonsd ale\%20P.,\%20Vavoula\%20G.\%20and\%20Sharples\%20M.,\%20Literature\%20Review\% 20in\%20Mobile\%20Technologies\%20and\%20Learning.pdf (accessed 6th May 2009).

Okolo, C. (2006). Using video to teach content-area information: How can the web help teachers? Journal of Special Education Technology, 21 (3), 48-51.

O’Neill, G., \& McMahon, T. (2005). Student-centred learning: what does it mean for students and lecturers? Dublin: AISHE, 2005. URL:

http://www.aishe.org/readings/2005-1/ (accessed 6th February 2008).

O'Toole, M. (2007). The influence of culture on the pedagogical and learning process in apprenticeship education. Proceedings of the $6^{\text {th }}$ ITAC Conference. Dundalk: Dundalk Institute of Technology. URL:

http://ww2.dkit.ie/about dkit/events/events news/6th annual itac conference present ations (accessed 16th January 2008).

Prensky, M. (2004). What can you learn from a cell phone? Almost anything! Innovate Online Magazine, 1 (5). URL:

http://www.innovateonline.info/index.php?view=article\&id=83 (accessed 6th May 2009).

Prensky, M. (2001). Digital natives digital immigrants Part 1. On the Horizon, 9 (5).

URL:

http://www.marcprensky.com/writing/Prensky\%20\%20Digital\%20Natives,\%20Digital\%2 Olmmigrants\%20-\%20Part1.pdf (accessed 16th October 2009).

Quinn, C. (2011). Mobile Learning: Landscape and Trends. The eLearning Guild. URL: http://www.elearningguild.com (accessed $7^{\text {th }}$ October 2011)

Reece, I., \& Walker, S. (2000). Teaching, training and learning a practical guide (4th ed.). Sunderland: Business Education Publishers Limited.

Romanov, K., \& Nevgi, A. (2007). Do medical students watch video clips in eLearning and do these facilitate learning? Medical Teacher, 29 (5), 490-494. 
Sewell, G. (2008). A new recipe for learning: blended mobile learning for the baking trades. The knowledge Tree, 17. URL:

http://kt.flexiblelearning.net.au/tkt2008/wpcontent/uploads/2008/10/kt2008 ed17 article gary sewell1.pdf (accessed 12th May 2009).

Sharples, M., Taylor, J., \& Vavoula, G. (2006). A Theory of Learning for the Mobile Age. URL: http://kn.open.ac.uk/public/document.cfm?docid=8558 (accessed 19th March 2010)

Shudong, W., \& Higgins, M. (2006). Limitations of mobile phone learning. The JALT CAL Journal, 2 (1), 3-14. URL: http://www.jaltcall.org/journal/articles/2 1 Wang.pdf (accessed 25th May 2009).

Shuler, C. (2009). Pockets of potential: Using mobile technologies to promote childern's learning. New York: The Joan Ganz Cooney Center at Sesame Workshop. URL: http://www.edweek.org/dd/articles/2009/01/09/04mobile.h02.html (accessed 20th November 2009).

Siemens, G. (2004). Connectivism: A learning theory for the digital age.

Elearningspace. URL: http://www.elearnspace.org/Articles/connectivism.htm (accessed 13th May 2009).

Stenhouse, L. (1975). An introduction to curriculum research and development. London: Heinemann.

Toohey, S. (1999). Designing courses for higher education. Buckingham: SRHE and Open University Press.

Traxler, J. (2005). Strategic aspects of wireless and mobile learning. Landscape study in wireless and mobile learning in the post-16 sector. JISC. URL:

http://www.jisc.ac.uk/whatwedo/programmes/elearninginnovation/outcomes.aspx (accessed 17th May 2009).

Vavoula, G., \& Sharples, M. (2008). Challenges in evaluation mobile learning. Proceedings of the mLearning Conference, Wolverhampton: University of Wolverhampton Technology Centre. p. 296-303. URL:

http://www.scit.wlv.ac.uk/brendan/mLearn2008.pdf (accessed 10th May 2009).

Whitaker, J. (2005). Teaching math with video streaming. Media \& Methods, 41 (4), 32.

Whitehead, J. (1988). Creating a living educational theory from questions of the kind, 'how do I improve my practice? Cambridge journal of Education, 19 (1), 41-52. URL: http://www.actionresearch.net/writings/livtheory.html (accessed 18th February 2010).

Zuber-Skerritt, O. (1984). Video in higher education. London: Kogan Page. 